\title{
PENGUJIAN PUPUK HAYATI KALBAR UNTUK MENINGKATKAN PRODUKTIVITAS TANAMAN KEDELAI (Glycine max) var. BALURAN
}

\section{THE TEST OF KALBAR BIOFERTILIZER POTENCY FOR INCREASING SOYBEAN (Glycine max) var. BALURAN PRODUCTIVITY}

\author{
YB. Subowo, Arwan Sugiharto, Suliasih dan Sri Widawati \\ Puslit Biologi - LIPI, Bogor \\ E-mail: yosubowo@yahoo.com
}

\begin{abstract}
ABSTRAK
Penelitian mengarah pada evaluasi kemampuan dari pupuk hayati kalbar untuk meningkatkan produktivitas dari tanaman kedelai. Percobaan pada plot percobaan lapangan di LIPI Cibinong. Kacang kedelai( Glycine max ) variasi Baluran diperlakukan dengan satu rangkaian pupuk yaitu: Nitrogen berisi kompos mikroba perbaikan, Fosfat berisi kompos mikroba solubilizing, kompos mengandung lignocelullosic menurunkan populasi jamur, Pupuk hayati Kalbar (Kompos memperbaiki kandungan nitrogem, Fosfat solubilizing dan lignocellulosic mengurangi derajat mikroba), pupuk kimia, kompos dan kontrol. Kenaikan pupuk berat segar dari biomass, angka dari daun-daun, angka buah polong, dan berat dari biji diamati. Nitrogen, Fosfat dan Karbon yang berada pada tanah sebelum tanaman, saat fase generatif pembungaan dan saat panen. Hasil aplikasi pengujian pupuk kalbar mampu meningkatkan Karbon (C ), Nitrogen (N) dan Phosphor (P ) konten pada tanah. Perlakuan ini juga meningkatkan berat segar dari biomass (22\%), buah polong (11, 11\%) dan berat dari biji (12,22\%).
\end{abstract}

Kata kunci: biofertilizer, mikroba, produktifitas, kedelai

ABSTRACT

Research aimed to evaluate the ability of kalbar biofertilizer to improve productivity of soybean. Experiment was conducted in the field experimental plot of Cibinong Science Centre. Soybean (Glycine max) var Baluran was treated with a series of fertilizer i.e.: compost containing Nitrogen fixing microbes, compost containing Phosphate solubilizing microbes, compost containing lignocelullosic degrading fungus, Kalbar biofertilizer (compost containing Nitrogen fixing, Phosphate solubilizing and lignocellulosic degrading microbes), chemist fertilizer, compost and control. The height of plant, fresh weight of biomass, number of leaves, pod number, and weight of seed were observed. The Nitrogen, Phosphate and Carbon which exist on the soil observed before planting, while flowering and while harvesting. The result was the application of kalbar biofertilizer able to increase the Carbon (C), Nitrogen $(N)$ and Phosphor $(P)$ content in the soil. This treatment also increased the fresh weight of biomass (22\%), the number of pods $(11,11 \%)$ and the weight of seed $(12,22 \%)$.

Key words: biofertilizer, microbes, productivity, soy bean

\section{PENDAHULUAN}

Pertanian organik adalah teknik pertanian tanpa menggunakan pupuk, pestisida dan hormon tumbuh kimia. Tujuan utama pertanian organik adalah menyediakan produk-produk pertanian terutama bahan pangan yang aman bagi kesehatan produsen dan konsumennya serta tidak merusak lingkungan (Anonim, 2002). Walaupun hasil panen melalui metode organik memang 20 persen lebih rendah dibanding pertanian konvensional yang melibatkan penggunaan pestisida. Namun keuntungan ekologis yang diraih lewat metode organik jauh lebih besar (Susanti, 2002). Dalam sistim pertanian ini masih dibutuhkan pupuk untuk meningkatkan produktivitas tanaman. Fungsi pupuk kimia digantikan oleh sejumlah mikroba yang mempunyai potensi dalam mendukung kesuburan tanah. Pupuk yang berisi mikroba penyubur tanah dikenal sebagai pupuk hayati (Biofertilizer). Biofertilizer arti umumnya adalah pupuk yang mengandung mikroorganisme hidup dan diharapkan aktivitasnya akan berpengaruh pada ekosistim tanah dan menghasilkan substansi yang menguntungkan untuk tanaman (Parr et al, 2002).

Pupuk hayati kalbar yang dimaksud di sini adalah kompos steril yang ditambah beberapa mikroorganisme hidup hasil isolasi dari beberapa 
lingkungan ekstrem di Kalimantan Barat, seperti: tanah gambut di daerah Rasau Jaya, tanah Kering di daerah Mandor, Tanah payau di daerah Mempawah dan Singkawang, tanah pantai di Singkawang. Selain itu beberapa isolat mikroba juga berasal dari tanaman di Kebun Raya Cibodas dan Puncak. Kelompok mikroorganisme hasil isolasi terdiri dari Bakteri Pelarut Posfat, Bakteri Penambat Nitrogen, Jamur pelarut Posfat, dan Jamur pendegradasi lignoselulosa.

Penambahan mikroba pelarut Posfat ke dalam tanah akan membantu pertumbuhan tanaman. Menurut Gaind and Gaur (1991) mikroba pelarut Phospat dapat membantu dalam penyediaan unsur $\mathrm{P}$ tanah, misalnya Bacillus subtilis, Bacillus circulans dan Aspergillus niger yang mampu melarutkan tricalsium phosphat pada suhu $35^{\circ} \mathrm{C}, 40^{\circ} \mathrm{C}$ dan $45^{\circ} \mathrm{C}$. Whitelaw et al. (2005) juga melaporkan bahwa Penicillium radicum (sp nov) dapat melarutkan Posfat pada tanah dengan $\mathrm{pH}$ rendah (pH 5). Unsur $\mathrm{N}$ (Nitrogen) dapat merangsang pertumbuhan tanaman secara keseluruhan serta berfungsi untuk sintesa asam amino dan protein dalam tanaman. Beberapa mikroba dapat menyediakan unsur $\mathrm{N}$ bagi tanaman. Pada percobaan yang dilakukan Chandrasekar et al (2005) terbukti bahwa pupuk yang mengandung Azotobacter dan Azospirillum dapat meningkatkan pertumbuhan dan hasil, tanaman Echinochloa frumentacea.

Tanaman mengambil unsur $\mathrm{C}$ (Carbon) dari udara dalam bentuk $\mathrm{CO}_{2}$ untuk bahan fotosintesa. Unsur C yang ada di dalam tanah digunakan oleh sejumlah mikroba tanah termasuk mikroba penyubur. Penggunaan mikroba pendegradasi senyawa lignoselulosa sebagai pupuk akan menjaga ketersediaan unsur C dalam tanah. Menurut Ahmed et al (2001) bakteri Cellulomonas atau jamur Chaetomium menghasilkan enzim selulase yang dapat menguraikan selulosa menjadi rantai yang lebih pendek atau gula demikian juga Trichoderma reesei menghasilkan enzim selulase.Masingmasing mikroorganisme penyusun pupuk hayati kalbar pernah diuji dan dapat meningkatkan produktivitas tanaman. Gabungan dari mikroorganisme ini merupakan penyusun pupuk hayati kalbar. Pupuk ini belum pernah dicoba pada tanaman. Oleh karena itu dilakukan pengujian pupuk hayati kalbar pada tanaman kedelai varietas Baluran.

\section{BAHAN DAN METODE}

\section{Bahan}

Mikroorganisme hasil isolasi dari lingkungan ekstrem di Kalimantan Barat dan
Jawa Barat terdiri: Bakteri pelarut Posfat (Citrobacter sp, Bacillus thuringensis, Bacillus megaterium, Nitrosomonas sp, Spaerotillus natans, Chromobacterium lividum, Bacterium sp, Pseudomonas fluorescent, Klebsiella sp); Jamur Pelarut Posfat (Penicillium sp, Aspergillus sp); Bakteri Penambat Nitrogen, (Rhizobium leguminosarum, Azotobacter tictus, Azotobacter sp, Azospirillum sp); Jamur pendegradasi lignoselulosa (Penicillium sp , Aspergillus sp, Trichoderma sp).

Bahan yang digunakan: kompos steril, pupuk kimia (urea dan TSP), lahan percobaan, bibit kedelai varietas Baluran, bak plastik, kantung plastik, neraca, penggaris, spektrofotometer. Media untuk perbanyakan sel: media khusus Azotobacter, Pvikoskaya, Yema, media khusus Azospirilum, nutrien agar, Pottato Dektrosa Agar, Taoge agar.

\section{Pupuk}

Pupuk hayati kalbar merupakan campuran mikroba hasil isolasi dari Kalimantan Barat dan Jawa Barat dengan kompos steril. Kompos dimaksudkan sebagai pembawa (carrier). Mikroba ditumbuhkan pada media cair, kemudian kultur diinkubasi pada suhu kamar sambil digojog di atas shaker dengan kecepatan 115 rpm. Setelah 1 minggu sel bakteri dan miselium jamur dipanen, kemudian dicampur dengan kompos steril. Campuran ini diinkubasi pada suhu ruang selama 3 minggu, setelah itu pupuk hayati kalbar siap dipakai. Perlakuan lain terdiri: Campuran kompos steril dengan mikroba pelarut Posfat selanjutnya disebut Pupuk P; campuran kompos steril dengan bakteri penambat $\mathrm{N}$ disebut Pupuk N; campuran kompos steril dengan jamur pengurai lignoselulosa disebut pupuk C; pupuk kimia (Urea dan TSP); kompos steril, kontrol.

\section{Lahan percobaan}

Lahan percobaan yang digunakan bertempat di belakang rumah kaca di Cibinong Science Centre berupa lahan datar. Pengolahan tanah dilakukan dengan pembalikan tanah, kemudian tanah dihaluskan. Setelah itu tanah dibuat guludan-guludan dengan ukuran $2 \times 2$ meter sebanyak 35 buah. Pada masing-masing guludan dibuat lubang-lubang untuk menanam bibit kedelai sebanyak 20 buah, yaitu 5 deret ke kanan dan 4 deret ke belakang.

\section{Penanaman kedelai}

Bibit kedelai dimasukkan pada lubanglubang di tiap guludan, masing-masing lubang diisi 5 biji, kemudian pupuk diisikan pada tiap 
lubang sebanyak satu takar gelas sesuai dengan rancangan perlakuan.

\section{Pemeliharaan tanaman}

Saat tanaman berumur satu bulan, dilakukan penyiangan untuk membersihkan rumput dan menggemburkan tanah agar tanaman kedelai tumbuh dengan baik. Penyiangan dilakukan pada semua tanaman dengan cara yang sama. Selain itu juga dilakukan pengurangan tanaman sehingga pada tiap lubang hanya berisi 2 tanaman.

\section{Rancangan percobaan}

Penelitian ini menggunakan Rancangan Acak Lengkap, perlakuan yang digunakan ada 7 macam, yaitu: (1) Bakteri Penambat Nitrogen dalam kompos steril (Pupuk N), (2) Mikroba Pelarut Posfat dalam kompos steril (Pupuk P), (3) Jamur pengurai lignoselulosa dalam kompos steril (Pupuk C), (4) Pupuk hayati kalbar berisi semua mikroba dalam kompos steril, (5) Kompos steril, (6) Pupuk Kimia berisi Urea dan TSP, (7) Kontrol. Jumlah ulangan 100 buah. Parameter yang diamati meliputi: Kandungan kimia tanah, Tinggi tanaman, Jumlah daun, Bobot tanaman segar, Jumlah polong, Bobot kedelai.

\section{HASIL DAN PEMBAHASAN}

Pemberian pupuk hayati kalbar dan pupuk lainnya ternyata dapat meningkatkan kandungan unsur N, P dan C tanah. Pemakaian pupuk hayati kalbar meningkatkan kandungan $\mathrm{N}$ tanah dalam bentuk nitrit 0,09 ppm, kandungan $\mathrm{C}$ organik 2,87\% dan kandungan $\mathrm{P}$ tersedia 86,15\% sedangkan nitrat dan amonium mengalami penurunan 7,57\% dan 5,84 ppm (Tabel 1). Kandungan nitrit tanah sebelum perlakuan 0,02 ppm, nitrat 13,36 ppm, NH4 14,26 ppm, P tersedia $1,86 \%$ dan $\mathrm{C}$ organik $0,76 \%$.

Peningkatan unsur N, $\mathrm{P}$ dan $\mathrm{C}$ tanah merupakan akibat pemberian pupuk hayati yang mengandung mikroorganisme. Mikroorganisme pelarut $\mathrm{P}$, penambat $\mathrm{N}$ dan pendegradasi lignoselulosa menambah kandungan unsur-unsur tersebut dalam tanah. Menurut Muzuan et al. (2002) bahwa penggunaan pupuk berbasis mikroorganisme dapat memperbaiki atau memulihkan kondisi fisik, kimia dan biologi tanah serta dapat meningkatkan hasil tanaman.

Dari hasil panen terlihat bahwa masingmasing perlakuan menghasilkan tinggi tanaman yang berbeda. Hal ini kemungkinan dipengaruhi oleh pemberian perlakuan yang berbeda. Pemberian kompos menghasilkan tinggi tanaman paling besar $(66,064 \mathrm{~cm})$, kemudian diikuti perlakuan pupuk hayati, pupuk P, Pupuk C, pupuk $\mathrm{N}$, perlakuan pupuk kimia dan terakhir kontrol $(54,464 \mathrm{~cm})$ (Gambar 1). Perbedaan ratarata tinggi tanaman antar perlakuan ini hanya sedikit, bahkan secara statistik tidak berbeda nyata. Namun perbedaan ini juga disebabkan oleh perlakuan yang berbeda.

Perlakuan dengan kompos steril ternyata menghasilkan tinggi tanaman kedelai yang paling besar, yaitu 66,064 cm, hal ini berarti kompos disamping membuat tanah lebih gembur atau lebih berongga sehingga meningkatkan kandungan oksigen tanah juga menambah unsur hara yang dibutuhkan tanaman. Perlakuan dengan pupuk hayati menghasilkan tinggi tanaman tidak jauh berbeda dengan perlakuan kompos, yaitu 64,594 cm, dibandingkan dengan perlakuan yang lain, tinggi tanaman ke 2 perlakuan ini masih lebih tinggi. Kalau dilihat kandungan unsur $\mathrm{P}$ dalam tanah, ternyata kedua perlakuan ini memiliki kandungan yang sama yaitu $88,01 \%$, ini lebih tinggi dari perlakuan yang lain (Tabel 1). Unsur $\mathrm{P}$ berfungsi untuk pengangkutan energi hasil metabolisme dalam tanaman, merangsang pembelahan sel dan memperbesar jaringan sel (Anonim, 2007). Dengan kandungan $\mathrm{P}$ yang tinggi kemungkinan pertumbuhan tanaman lebih cepat.

Variabel berikutnya adalah jumlah daun; jumlah daun tanaman kedelai yang dihasilkan tiap perlakuan ternyata juga berbeda. Jumlah daun mengindikasikan pertumbuhan tanaman, semakin banyak jumlah daun yang dihasilkan maka pertumbuhan tanaman tersebut semakin baik. Dari 7 perlakuan yang dicoba pada tanaman kedelai varietas Baluran, ternyata jumlah daun yang paling besar dihasilkan oleh perlakuan pupuk hayati kalbar yaitu 29,464 helai kemudian perlakuan Kompos kemudian Pupuk P, Pupuk N, Pupuk kimia, Pupuk C dan terakhir perlakuan kontrol (24,398 helai). Perbedaan jumlah daun masing-masing perlakuan kecil sehingga secara statistik tidak berbeda nyata (Gambar 2).

Jumlah daun merupakan efek dari pertumbuhan tanaman. Perlakuan pupuk hayati dan kompos menghasilkan jumlah daun yang besar, hal ini juga terkait dengan kandungan unsur yang dibutuhkan oleh tanaman untuk pertumbuhan vegetatif. Pada kedua perlakuan tersebut kandungan unsur $\mathrm{N}, \mathrm{P}$ dan $\mathrm{C}$ adalah paling tinggi dibandingkan perlakuan yang lain. Unsur $\mathrm{N}$ berguna untuk merangsang pertumbuhan tanaman secara keseluruhan, merangsang pertumbuhan vegetativ dan berfungsi untuk sintesa asam amino dan protein dalam tanaman (Anonim, 2007). Dengan kandungan $\mathrm{N}$ dan $\mathrm{P}$ yang tinggi maka 
pertumbuhan daun dan pertumbuhan vegetativ tanaman akan lebih baik. Hal ini seperti yang dilaporkan Djayadi et al. (2000) bahwa pemberian pupuk hayati dan $25 \mathrm{~kg}$ N/ha meningkatkan hasil tembakau masing-masing sebesar 22\% daun basah dan 30\% krosok dibandingkan dengan perlakuan pupuk $25 \mathrm{~kg}$ N/ha saja.

Variabel selanjutnya adalah bobot tanaman segar, ini juga merupakan variabel pertumbuhan vegetativ. Dari 7 perlakuan ternyata menghasilkan bobot tanaman yang berbeda pada masing-masing perlakuan. Bobot paling besar diperoleh tanaman dengan perlakuan Pupuk hayati kalbar yaitu 118,73 g/tanaman kemudian perlakuan pupuk $\mathrm{P}$, perlakuan pupuk N, pupuk C, pupuk kimia, pupuk kompos dan terakhir kontrol (87,062 g). Perbedaan bobot tanaman antar perlakuan juga kecil sehingga secara statistik juga menunjukkan tidak berbeda nyata (Tabel 2).

Tabel 1. Kandungan unsur N, P dan C tanah saat tanaman berbunga

\begin{tabular}{llccccc}
\hline No & \multicolumn{1}{c}{ Perlakuan } & $\begin{array}{c}\text { Kadar Nitrit } \\
(\mathrm{ppm})\end{array}$ & $\begin{array}{c}\text { Kadar Nitrat } \\
(\mathrm{ppm})\end{array}$ & $\begin{array}{c}\text { Kadar } \\
\mathrm{NH}_{4}(\mathrm{ppm})\end{array}$ & $\begin{array}{c}\text { Kadar C } \\
\text { organik (\%) }\end{array}$ & $\begin{array}{c}\text { Kadar P } \\
\text { Tersedia (\%) }\end{array}$ \\
\hline 1 & Pupuk N & 0,08 & 5,28 & 7,21 & 2,80 & 39,89 \\
2 & Pupuk P & 0,10 & 8,56 & 7,92 & 2,61 & 69,62 \\
3 & Pupuk C & 0,08 & 7,05 & 6,14 & 3,15 & 53,34 \\
4 & Pupuk hayati & 0,11 & 5,79 & 8,42 & 3,63 & 88,01 \\
& kalbar & & & & & \\
5 & Kompos & 0,06 & 3,01 & 12,30 & 4,11 & 88,01 \\
6 & Pupuk kimia & 0,06 & 15,89 & 2673,35 & 1,25 & 1,05 \\
7 & Kontrol & 0,08 & 10,58 & 7,17 & 1,34 & 3,12 \\
\hline
\end{tabular}

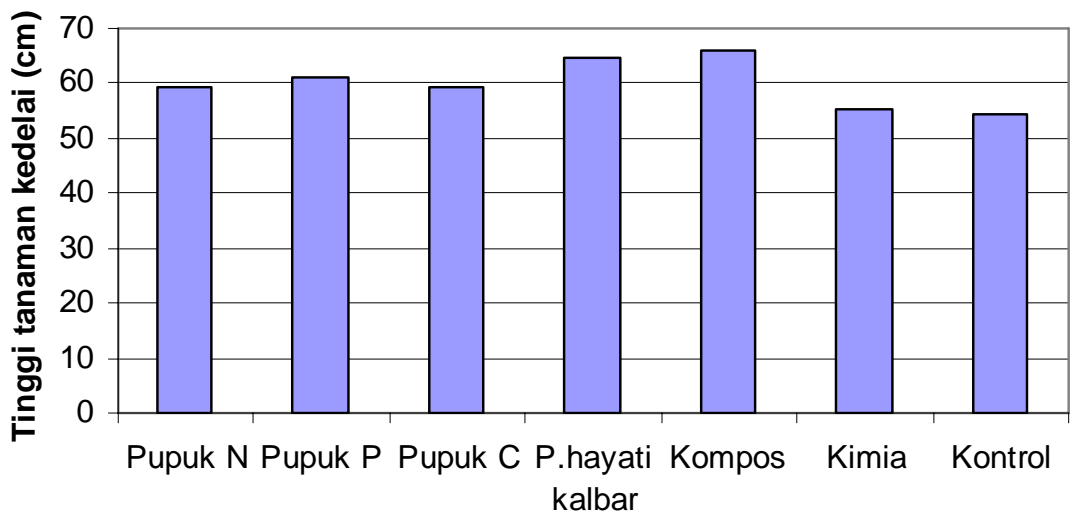

Perlakuan

Gambar 1. Tinggi tanaman kedelai setelah perlakuan

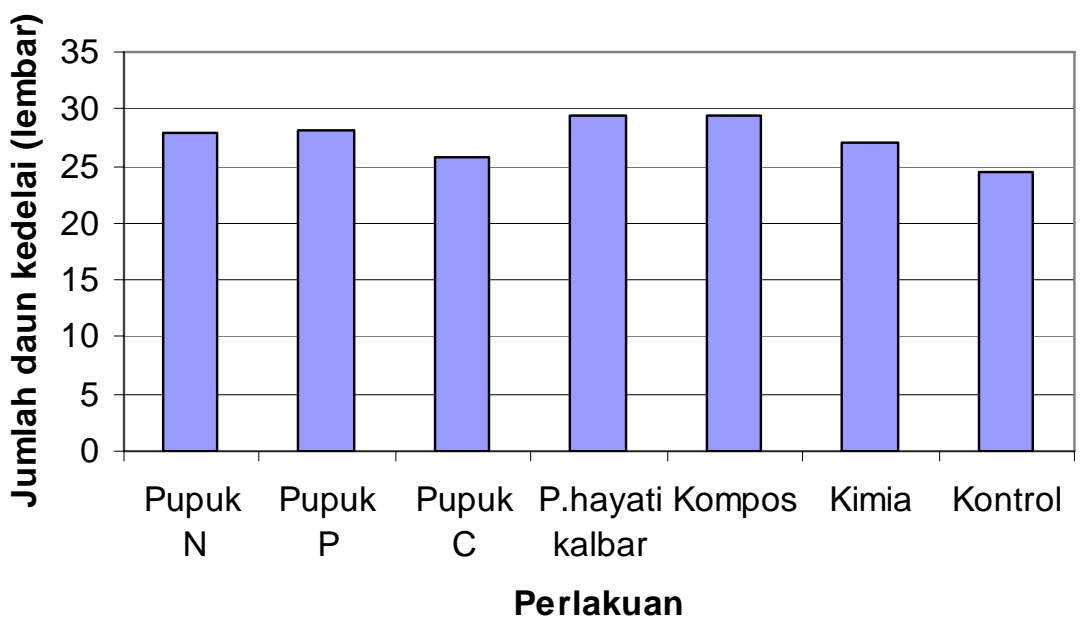

Gambar 2. Jumlah daun tanaman kedelai setelah perlakuan 
Tabel 2. Rata rata bobot tanaman segar

\begin{tabular}{crrrrrrr}
\hline No & $\begin{array}{c}\text { Pupuk N } \\
(\mathrm{g})\end{array}$ & $\begin{array}{c}\text { Pupuk P } \\
(\mathrm{g})\end{array}$ & $\begin{array}{c}\text { Pupuk C } \\
(\mathrm{g})\end{array}$ & $\begin{array}{c}\text { P. hayati kalbar } \\
(\mathrm{g})\end{array}$ & $\begin{array}{c}\text { Kompos } \\
(\mathrm{g})\end{array}$ & $\begin{array}{c}\text { P.kimia } \\
(\mathrm{g})\end{array}$ & $\begin{array}{c}\text { Kontrol } \\
(\mathrm{g})\end{array}$ \\
\hline 1 & 130,66 & 194,00 & 93,33 & 93,33 & 87,33 & 129,33 & 78,66 \\
2 & 94,66 & 81,33 & 112,66 & 232,66 & 117,66 & 99,00 & 106,33 \\
3 & 107,00 & 102,00 & 138,66 & 139,00 & 118,33 & 101,66 & 97,66 \\
4 & 95,00 & 103,66 & 98,66 & 56,66 & 56,66 & 46,66 & 93,33 \\
5 & 101,00 & 59,00 & 66,33 & 72,00 & 104,66 & 108,66 & 59,33 \\
Jml & 528,32 & 539,99 & 509,64 & 593,65 & 484,64 & 485,31 & 435,31 \\
Rata2 & 105,66 a & $107,99 \mathrm{a}$ & $101,92 \mathrm{a}$ & $118,73 \mathrm{a}$ & $96,92 \mathrm{a}$ & $97,06 \mathrm{a}$ & 87,06 a \\
\hline
\end{tabular}

Keterangan: Angka-angka yang diikuti huruf yang sama menunjukkan tidak berbeda nyata pada taraf uji $5 \%$

Tabel 3. Jumlah polong rata-rata tanaman kedelai

\begin{tabular}{crrrrrrr}
\hline No & $\begin{array}{c}\text { Pupuk } \\
\text { N (buah) }\end{array}$ & $\begin{array}{c}\text { Pupuk P } \\
\text { (buah) }\end{array}$ & $\begin{array}{c}\text { Pupuk C } \\
\text { (buah) }\end{array}$ & $\begin{array}{c}\text { P. hayati } \\
\text { kalbar (buah) }\end{array}$ & $\begin{array}{c}\text { Kompos } \\
\text { (buah) }\end{array}$ & $\begin{array}{c}\text { P.kimia } \\
\text { (buah) }\end{array}$ & $\begin{array}{c}\text { Kontrol } \\
\text { (buah) }\end{array}$ \\
\hline 1 & 67,33 & 113,00 & 62,66 & 63,33 & 76,66 & 104,33 & 73,66 \\
2 & 57,00 & 54,66 & 72,66 & 158 & 84,66 & 73,33 & 84,33 \\
3 & 83,00 & 94,66 & 80,66 & 106,66 & 84,66 & 70,66 & 80,33 \\
4 & 72,00 & 72,66 & 86,66 & 50,66 & 56,00 & 41,66 & 69,33 \\
5 & 107,33 & 50,33 & 61,33 & 75,33 & 103,33 & 92,33 & 60,66 \\
Jml & 386,66 & 385,31 & 363,97 & 453,98 & 405,31 & 382,31 & 368,31 \\
Rata2 & 77,33 a & 77,06 a & 72,79 a & $90,79 \mathrm{a}$ & 81,06 a & 76,46 a & 73,66 a \\
\hline
\end{tabular}

Tabel 4. Bobot kacang kedelai tiap petak (berisi 20 tanaman)

\begin{tabular}{cccccccc}
\hline \multirow{2}{*}{ No } & $\begin{array}{c}\text { Pupuk } \\
\text { N }(\mathrm{g})\end{array}$ & $\begin{array}{c}\text { Pupuk P } \\
(\mathrm{g})\end{array}$ & $\begin{array}{c}\text { Pupuk C } \\
(\mathrm{g})\end{array}$ & $\begin{array}{c}\text { P. hayati } \\
\text { kalbar }(\mathrm{g})\end{array}$ & $\begin{array}{c}\text { Kompos } \\
(\mathrm{g})\end{array}$ & $\begin{array}{c}\text { Kimia } \\
(\mathrm{g})\end{array}$ & $\begin{array}{c}\text { Kontrol } \\
(\mathrm{g})\end{array}$ \\
\hline 1 & 96 & 232 & 437,5 & 633 & 408 & 578 & 366 \\
2 & 54 & 322 & 711 & 987 & 695 & 412 & 707 \\
3 & 20 & 284 & 453 & 723 & 708 & 355 & 520 \\
4 & 22 & 97 & 426 & 328 & 380 & 298 & 468 \\
5 & 16 & 36 & 160 & 137 & 309 & 337 & 136 \\
Jml & 208 & 971 & 2187,5 & 2808 & 2500 & 1980 & 2197 \\
Rata2 & $41,6 \mathrm{a}$ & $226,2 \mathrm{a}$ & $437,5 \mathrm{~b}$ & $561,6 \mathrm{~b}$ & $500 \mathrm{~b}$ & $396 \mathrm{~b}$ & $439,4 \mathrm{~b}$ \\
\hline
\end{tabular}

Keterangan: Angka-angka yang diikuti huruf yang sama menunjukkan tidak berbeda nyata pada taraf uji $5 \%$

Keterangan: Angka-angka yang diikuti huruf yang sama menunjukkan tidak berbeda nyata pada taraf uji $5 \%$ Bobot tanaman segar juga mengindikasikan tingkat pertumbuhan tanaman. Semakin besar bobot tanaman berarti semakin banyak biomassa yang dihasilkan, dalam hal ini tentunya berkaitan dengan jumlah unsur hara yang tersedia di tanah. Pada perlakuan pupuk hayati, kandungan unsur $\mathrm{P}$ dan $\mathrm{C}$ dalam tanah paling tinggi dibandingkan perlakuan yang lain, demikian juga kandungan $\mathrm{N}$ dalam bentuk senyawa nitrit, kemungkinan hal ini yang mempengaruhi pertumbuhan tanaman kedelai. Dari ketiga parameter di atas terbukti bahwa pemberian mikroba dalam bentuk pupuk hayati ke dalam tanah akan meningkatkan pertumbuhan vegetatif tanaman kedelai dan dapat meningkatkan bobot tanaman segar 22\% dibandingkan perlakuan kompos. Seperti yang dilaporkan Nabil et. al (2007) bahwa pemberian mikroba campuran Rhizobia, Mycorrhiza dan
Pseudomonas dapat meningkatkan pertumbuhan vegetatif tanaman faba bean (Vicia faba) lebih tinggi dibandingkan pemberian pupuk NPK. Demikian juga yang dilaporkan oleh Xu (2000) pemberian inokulan mikrobia dalam bentuk EM pada tanaman Zea mays L cv Honey Bantam pada kondisi stres air dapat meningkatkan pertumbuhan lebih tinggi dibandingkan pemberian pupuk kimia.

Variabel berikutnya adalam jumlah polong. Tanaman yang menghasilkan jumlah polong banyak berarti pertumbuhan tanaman tersebut baik. Dari 7 perlakuan yang dicoba ternyata menghasilkan jumlah polong yang berbeda, paling besar dihasilkan oleh tanaman dengan perlakuan pupuk hayati yaitu 90,796 buah, kemudian pupuk kompos, pupuk N, pupuk $\mathrm{P}$, pupuk kimia, kontrol dan terakhir pupuk C (73,662 buah). Perbedaan jumlah polong antar masing-masing perlakuan juga kecil, secara statistik tidak beda nyata. Namun kecenderungan 
perbedaan jumlah polong ini juga disebabkan oleh perbedaan perlakuan (Tabel 3).

Pemberian pupuk hayati kalbar pada tanaman kedelai ternyata dapat meningkatkan jumlah polong sebanyak 11,11\% dibandingkan perlakuan kompos. Jumlah polong yang dihasilkan mengindikasikan pertumbuhan tanaman tersebut, semakin banyak jumlah polong yang dihasilkan maka pertumbuhannya semakin baik. Dalam percobaan ini perlakuan pupuk hayati menghasilkan jumlah polong paling banyak dibandingkan perlakuan lainnya. Hal ini berkaitan dengan kandungan unsur $\mathrm{P}$ dalam tanah, pada perlakuan pupuk hayati prototype kandungan $\mathrm{P}$ dalam tanah paling tinggi disbanding perlakuan yang lain. Unsur P berguna untuk merangsang pembungaan dan pembuahan dan merangsang pembentukan biji (Anonim, 2007).

Variabel berikutnya adalah Bobot kacang kedelai, untuk bobot kacang kedelai dihitung per petak yaitu sekitar 20 tanaman. Dari 7 perlakuan yang dicoba ternyata menghasilkan bobot kacang kedelai yang berbeda. Bobot kacang kedelai paling besar dihasilkan perlakuan pupuk hayati kalbar yaitu 561,6 g, kemudian perlakuan kompos, kontrol, pupuk C, pupuk kimia, pupuk $\mathrm{P}$ dan terakhir pupuk N (41,6 g) (Tabel 4). Perbedaan bobot kacang kedelai antar masingmasing perlakuan cukup besar dan secara statistik menunjukkan beda nyata.

Pemberian pupuk hayati kalbar dapat meningkatkan bobot kacang kedelai sebanyak 12,2\% dibandingkan perlakuan kompos. Ternyata juga menghasilkan bobot kacang kedelai paling besar dibandingkan perlakuan lain. Pemberian pupuk hayati kalbar ternyata meningkatkan kandungan $\mathrm{P}$ dalam tanah, hal ini akan merangsang pembentukan biji. Nampak bahwa pemberian pupuk hayati kalbar dapat meningkatkan produksi kacang kedelai. Nabil et. al (2007) melaporkan bahwa penggunaan inokulan campuran dapat meningkatkan produksi Vicia fabae. Demikian pula yang dilaporkan Mezuan et al (2002) bahwa pemberian pupuk hayati pada padi gogo akan meningkatkan jumlah anakan dengan nilai rata-rata tertinggi 2,58 batang. Dengan semakin banyak jumlah anakan maka jumlah padi yang dihasilkan juga semakin besar.

\section{KESIMPULAN}

Pemberian pupuk hayati kalbar dapat meningkatkan kandungan unsur $\mathrm{N}$ dalam bentuk nitrit, unsur $\mathrm{P}$ dan unsur $\mathrm{C}$ tanah. Pemakaian pupuk hayati kalbar juga meningkatkan bobot tanaman segar 22\%, jumlah polong $11,11 \%$ dan bobot kacang kedelai 12,2\%.

\section{DAFTAR PUSTAKA}

Ahmed. Z, H. Banu, M.M Rahman, F. Akhter and S. Haque. 2001. Microbial activity on the degradation of lignocellulosic polysaccharides. Online Journal of Biological Sciences 1(10): 993-997.

Anonim. 2002. Prospek Pertanian Organik di Indonesia Badan Penelitian dan Pengembangan Pertanian, Jakarta. Online. Available at webadm@litbang.deptan.go.id Anonim. 2007. Fungsi Unsur Hara Makro (N-PK).Forum Diskusi Trubus. Kamis, 29 Nov 2007.

Chandrasekar B.R, G. Ambroseand N.Jayabalan. 2005). Influence of biofertilizers and nitrogen source level on the growth and yield of Echinochloa frumentacea (Roxb) Link. Journal of Agricultural Technology 1(2):223-234.

Djayadi, A.S, Murdiyati, Titiek Y, Heri. I. 2000. Efektivitas pupuk hayati dan pupuk nitrogen (ZA) dalam meningkatkan hasil dan mutu tembakau Virginia serta populasi bakteri dan kadar $\mathrm{N}$ total tanah. Jurnal penelitian Tanaman Industri 6(1): 18-23.

Gaind, S and A.C. Gaur. 1991. Thermotolerant phosphate solubilizing microorganism and their interaction with mung bean. Plant and Soil (Historitical Archive) 133 (1): 141149.Hui-lian Xu. 2000. Effect of Microbial Inoculant, Organic Fertilizer and Chemichal Fertilizer on Water Stress Resistance of Sweet Corn. The Haworth Press, Inc. Nagano, Japan

Mezuan, I.P Handayani dan E. Inoriah. 2002. Penerapan formulasi pupuk hayati untuk budidaya padi gogo. Jurnal Ilmu-Ilmu Pertanian Indonesia, 4(1): 27-34

Nabil .E, El-Wakeil and T.N El-Sebai. 2007. Role of Biofertilizer on Faba Bean Growth, Yield, and its Effect on Bean Aphid and the Associated Predators. Research Journal of Agriculture and Biological Sciences, 3(6):800-807. 
Parr J.F, Hornick S.B, and Papendick R.I. 2002. Transition from conventional agriculture to natural farmaingsystem: The role of microbial inoculants and Biofertilizer. http://www.emtech.org/data/pdf.
Susanti F.R. 2002. Pertanian Organik Mampu Tingkatkan Kesuburan Tanah. Harian Sinar Harapan, Senin 3 Juni 2002.

Whitelaw M.A, T.J. Harden and G.L. Bender. 2005. Plant growth promotion of wheat inoculated with Penicillium radicum sp.nov. Australian Journal of Soil 